\title{
Effect of purified alkaline phosphatase from Bacillus licheniformis on growth of Zea mays $\mathrm{L}$.
}

\author{
Priyanka Singh ${ }^{* 1}$ \& Rathindra Mohan Banik ${ }^{2}$ \\ ${ }^{1}$ Department of Bioscience and Biotechnology, Banasthali Vidyapith, Rajasthan 304 022, India \\ ${ }^{2}$ School of Biochemical Engineering, IIT (BHU), Varanasi 221 005, India
}

\section{Article history}

Received: 27 November 2019 Accepted: 26 December 2019 Published: 31 December 2019

\section{Publisher}

Horizon e-Publishing Group

\section{*Correspondence}

Priyanka Singh

凶priyay20@gmail.com

\begin{abstract}
Some soil microbes have the capability to solubilize mineral phosphate into organic phosphorous and used as biofertilizer to improve crop productivity in agricultural field. In this study, phosphate solubilization assay was carried out onto media plates containing calcium phsophate precipitated nutrient agar media for bacterial strains like Bacillus megaterium MTCC 453, Bacillus subtilis MTCC 1134, Bacillus licheniformis MTCC 2312, Pseudomonas aeruginosa MTCC 424, Escherichia coli MTCC 570. Among these bacterial strains, B. licheniformis MTCC 2312 showed largest clear zone of phosphate solubilzation and maximum activity of alkaline phosphatase. The enzyme alkaline phosphatase was purified from B. licheniformis MTCC 2312 with purification fold 3.52 and specific activity $295.89 \mathrm{U} \mathrm{mg}^{-1}$ protein using DEAE-sepharose chromatography. This enzyme showed molecular weight as $60 \mathrm{KD}$, thermostability upto $50{ }^{\circ} \mathrm{C}$, pH stability up to 8.5 and Michaelis constant $\left(\mathrm{K}_{\mathrm{m}}\right)$ and maximum activity $\left(\mathrm{V}_{\max }\right)$ as $2.30 \mathrm{mM}$ and $2223 \mathrm{U} \mathrm{ml}^{-1}$ respectively. The lyophilized powder of this enzyme was further supplemented with media components for the growth of Zea mays for carrying tissue culture experiment. The sterilized soil supplemented with alkaline phosphatase improved the total height, dry weight, \% phosphate content in the stem and root of Zea mays by 3.07, 3.15, 2.35 and 1.76 fold respectively compared to control set. This enzyme could be used at large extent as effective biofertilizer for the agricultural industry.
\end{abstract}

Keywords: Alkaline phosphatase; Bacillus licheniformis; Biofertilizer; Zea mays

Citation: Singh P, Banik R M. Effect of purified alkaline phosphatase from Bacillus licheniformis on growth of Zea mays L. Plant Science Today 2019;6(sp1):583-589. https://doi.org/10.14719/pst.2019.6.sp1.676

Copyright: (C) Singh and Banik (2019). This is an open-access article distributed under the terms of the Creative Commons Attribution License, which permits unrestricted use, distribution, and reproduction in any medium, provided the original author and source are credited (https://creativecommons.org/licenses/by/4.0/).

Indexing: Plant Science Today is covered by Scopus, Web of Science, BIOSIS Previews, ESCI, CAS, AGRIS, UGC-CARE, CABI, Google Scholar, etc. Full list at http://www.plantsciencetoday.online

\section{Introduction}

Phosphate anions are extremely reactive and present in insoluble complex as phosphorylated derivatives of $\mathrm{Ca}^{2+}, \mathrm{Mg}^{2+}, \mathrm{Fe}^{3+}, \mathrm{Al}^{3+}$ in soil samples and unavailable for plant $(1,2)$. Some soil microbes have the capability to solubilize these immobilized insoluble phosphate either by secreting organic acids or phosphohydrolase enzyme $(3,4)$. Several microbes have been reported to exhibit phosphate solubilization activity for hydrolyzing insoluble complex of phosphate like dicalcium phosphate, hydroxyapatite, tricalcium phosphate into inorganic phosphate $(5,6)$. Bacterial strains like Bacillus, Pseudomonas, Aereobacter, Burkholderia, Erwinia, Rhizobium, Agrobacterium, Microccocus, Achromobacter, Flavobacterium, Paenibacillus exhibited phosphate solubilization activity (3, 7-15). Soil inoculated with these phosphate-solubilizing 
bacteria (PSB) improved the yield and productivity of some crops (2). In conjugation with phosphatesolubilizing bacteria, these biofertilizers should provide a cheap source of chemical phosphate fertilizer for crop production (16). Hence, phosphate-solubilizing bacteria have the potential to improve crop production in this area. The performance of these microbes for hydrolysis of insoluble complex of phosphate is affected severely under climatic stress of high salt, $\mathrm{pH}$ and temperature. In the alkaline soils of the tropical field, the optimum concentration of salts, $\mathrm{pH}$ value and temperature range varies from 1-2\%, 7.5-10.5, $35-45{ }^{\circ} \mathrm{C}$ respectively. These climate changes result variance in survivability of phosphate-solubilizing bacteria (17-19). Bacillus species like $B$. brevis, $B$. licheniformis, $B$. megaterium, $B$. polymixa, $B$. thruringenisis have unique characteristics of producing stress resistant spores which can withstand a wide range of $\mathrm{pH}$ and temperature of soil $(3,17)$. Bacillus species are also known to produce large amount of alkaline phosphatase enzyme extracellularly which easily solubilize mineralized phosphate of soil and thereby enhance the phosphorous uptake by the plant leading to improve crop productivity. There is not any scientific report available till date for use of purified alkaline phosphatase secreted from Bacillus spp. for improving productivity of crop plant. This study will highlight the biochemical characterization of alkaline phosphatase from $B$. licheniformis and its application as biofertilizer for growth of Zea mays plant.

\section{Materials and Methods}

\section{Selection of potent phosphate solubilzing bacteria}

Bacterial strains (procured from IMTECH Chandigarh) like $B$. megaterium MTCC 453, $B$. subtilis MTCC 1134, B. licheniformis MTCC 2312, $P$. aeruginosa MTCC 424, E.coli MTCC 570 were maintained in nutrient agar media $(\mathrm{pH} 7.5)$ and subcultured once in two weeks. They were grown in growth media ( $\mathrm{pH} 7.5$ ) containing $1 \%$ glucose, $0.1 \%$ yeast extract, $1 \%$ peptone, $0.002 \% \mathrm{KH}_{2} \mathrm{PO}_{4}$, $0.02 \% \mathrm{MgSO}_{4} .7 \mathrm{H}_{2} \mathrm{O}, 0.5 \% \mathrm{NaCl}$ and incubated at 35 ${ }^{\circ} \mathrm{C}, 120 \mathrm{rpm}$ for $72 \mathrm{~h}$. The phosphate solubilization assay was carried out by streaking calcium phsophate precipitated nutrient agar media plates containing $10 \% \mathrm{~K}_{2} \mathrm{HPO}_{4}, 10 \% \mathrm{CaCl}_{2}$ and incubating at $27{ }^{\circ} \mathrm{C}$ for $72 \mathrm{~h}$ with the suspension of these bacterial strains (20). Clear zone of phosphate solubilization was measured around bacterial colony after 14 days and the bacterial strain showing largest zone was selected for further study.

The fermentative broth culture was centrifuged at $10,000 \mathrm{~g}$ at $30{ }^{\circ} \mathrm{C}$ for $15 \mathrm{~min}$ and cell free supernatant was used for estimation of activity of alkaline phosphatase. The activity was measured spectrophotometrically at $415 \mathrm{~nm}$ by

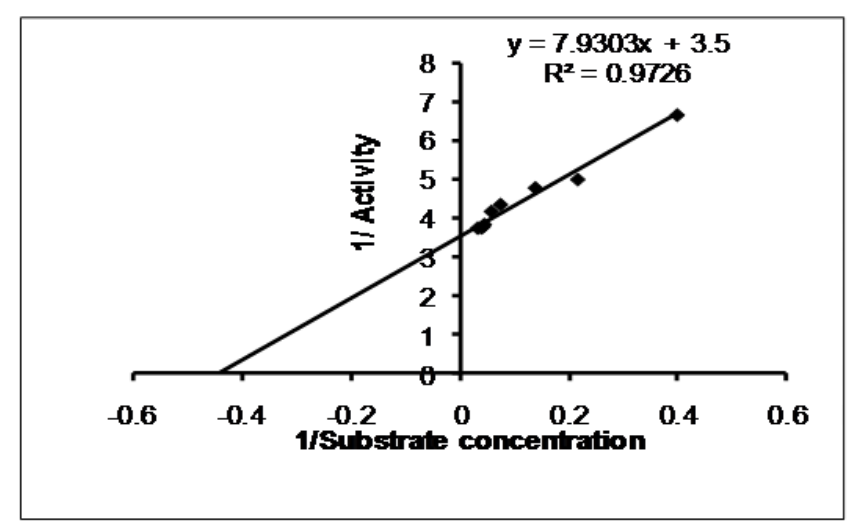

Fig. 1. Line weaver Burk plot for purified alkaline phosphatase.

monitoring the release of $\mathrm{p}$-nitrophenol from $\mathrm{p}$ nitrophenyl phosphate disodium salt (pNPP) (21, 22 ). One unit of alkaline phosphatase is defined as the amount of the enzyme required for liberation of $1 \mu$ mole of p-nitro phenol per $\mathrm{ml}$ of reaction mixture per minute under standard condition.

\section{Purification of alkaline phosphatase}

The fermentative broth culture was centrifuged at $10000 \times \mathrm{g}$ for $15 \mathrm{~min}$ at $4{ }^{\circ} \mathrm{C}$ and collected supernatant was used as crude extract. The crude extract was partially purified by precipitating with $30-80 \%$ ammonium sulfate saturation and the pellet was dissolved in $50 \mathrm{mM}$ Tris- $\mathrm{HCl}$ ( $\mathrm{pH} 8.0$ ). Each pellet suspension was dialysed against Tris $\mathrm{HCl}$ buffer and dialysed fraction was subjected to ion exchange chromatography using DEAESephadex G-200. Activity of alkaline phosphatase was estimated in each fraction and total protein was simultaneously determined by Bradford method. SDS-PAGE electrophoresis was used for estimation of molecular weight of purified extract of alkaline phosphatase.

\section{Characterization of alkaline Phosphatase}

Kinetic constant values $\mathrm{K}_{\mathrm{m}}$ and $\mathrm{V}_{\max }$ for purified alkaline phosphatase were determined by plotting Lineweaver Burk plot for different substrate concentration (2.0-30 mM) (Fig. 1). The value of optimum $\mathrm{pH}$ was estimated by incubating the reaction mixture in different range of $\mathrm{pH}$ values (8.5 to 12.5 ) at $50{ }^{\circ} \mathrm{C}$ for $20 \mathrm{~min}$ and temperature was optimized by incubating the mixture with optimum $\mathrm{pH}$ at different temperature $\left(40\right.$ to $\left.100{ }^{\circ} \mathrm{C}\right)$ for $20 \mathrm{~min}$. The thermostability was determined by incubating purified enzyme extract at temperature $50{ }^{\circ} \mathrm{C}$ for intervals of $2,4,6,8,10,20,40,50$ and 100 h. Substrate specificity test for alkaline phosphatase was done by analyzing inorganic phosphate obtained from hydrolysis of monosubstituted phosphate linkages compounds by alkaline phosphatase. Lowry-Lopez method (23) was used to determine the concentration of released inorganic phosphate. The reaction mixture containing alkaline phosphatase enzyme and phosphorylated compounds $(5.4 \mathrm{mM}$-Tris- $\mathrm{HCl}$, $\mathrm{pH}$ 9.5) was incubated at $50{ }^{\circ} \mathrm{C}$ for $20 \mathrm{~min}$. 


\section{Growth of plant in treated and untreated soil}

Seeds of Zea mays were washed with autoclaved water and sterilized with sodium hypochlorite $(0.5 \%)$. These sterilized seeds were germinated in pot filled with sterilized soil supplemented with calcium phosphate $\left[\mathrm{Ca}_{5}\left(\mathrm{PO}_{4}\right)_{3} \mathrm{OH}\right]$ at different doses $\left(0,200\right.$ and $375 \mathrm{mg} \mathrm{kg}^{-1}$ soil). Three pots were filled with soil having different doses of calcium phosphate as control sets and three pots were filled with calcium phosphate supplemented sterilized soil along with lyophiillized powder of alkaline phosphatase as experimental sets. Sterilized seeds of Zea mays were inserted into all these pots and allowed to germinate for 60days in greenhouse under controlled conditions at temperature varying $35-50{ }^{\circ} \mathrm{C}$. Height of the plant and percent of phosphate content in stem and roots was recorded. Plant samples of each control and experimental set after harvesting were dried in oven at $65{ }^{\circ} \mathrm{C}$ to obtain total plant biomass (Dry weight).

\section{Determination of percent phosphate content}

Vanado-molybdophosphoric acid reagent was prepared by mixing ammonium molybdate $\left(7.5 \mathrm{~g} \mathrm{l}^{-}\right.$ $\left.{ }^{1}\right)$ and concentrated ammonium metavandate $\left(0.6875 \mathrm{~g} \mathrm{l}^{-1}\right)$. Standard phosphate solution $\left(50 \mathrm{mg} \mathrm{l}^{-}\right.$ ${ }^{1}$ ) was prepared by adding $0.2195 \mathrm{~g} \mathrm{KH}_{2} \mathrm{PO}_{4}$ to 100 $\mathrm{ml}$ distilled water and acidifying with $25 \mathrm{ml}$ of $7 \mathrm{~N}$ $\mathrm{H}_{2} \mathrm{SO}_{4}$. Phosphate content in plant sample was estimated by mixing $10 \mathrm{ml}$ acid digest of plant sample with $10 \mathrm{ml}$ of the vanadate-molybdate reagent, diluting solutions to $50 \mathrm{ml}$ and measuring absorbance at $420 \mathrm{~nm}$ after $10 \mathrm{~min}$. The standard curve obtained for estimation of phosphate content has been shown in Fig. 2.

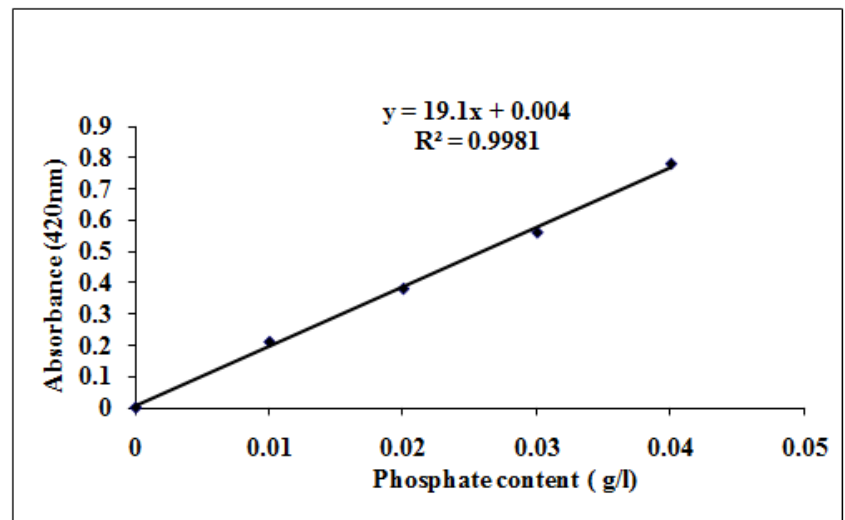

Fig. 2. Standard curve for estimation of phosphate content.

\section{Results and Discussion}

Bacterial strains like B. megaterium MTCC 453, $B$. subtilis MTCC 1134, B. licheniformis MTCC 2312, $P$. aeruginosa MTCC 424, E. coli MTCC 570 were streaked on nutrient agar media plates supplemented with calcium phosphate and screened on the basis of zone of clearance due to phosphate solubilizing assay (Fig. 3) and estimation of activity of alkaline phosphatase (Fig. 4). B. licheniformis MTCC 2312 showed largest clear

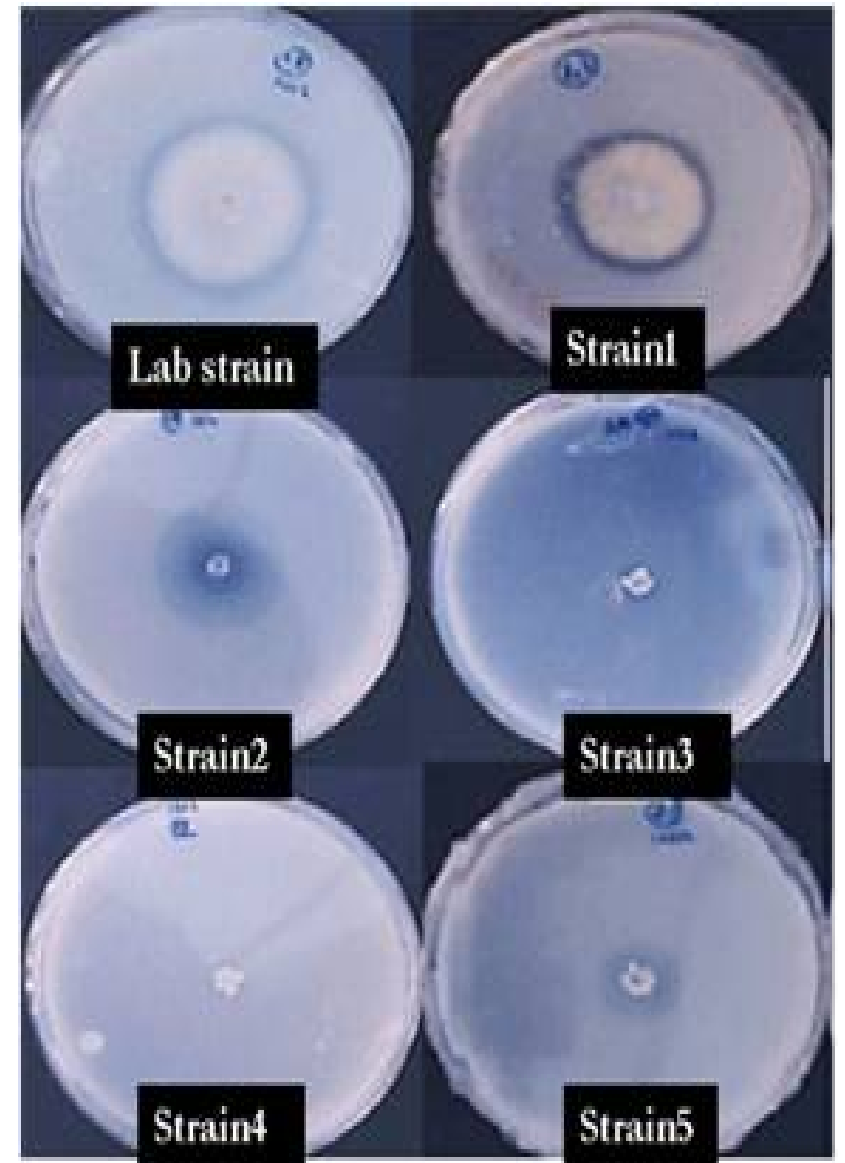

Fig. 3. Clear zone of phosphate solubilization of lab strain (Bacillus licheniformis MTCC 2312, strain 1 (Bacillus megaterium MTCC 453), strain2 (Bacillus subtilis MTCC 1134), strain 3,4 Escherichia coli MTCC 570 and Strain 5 (Pseudomonas aeruginosa MTCC 424).

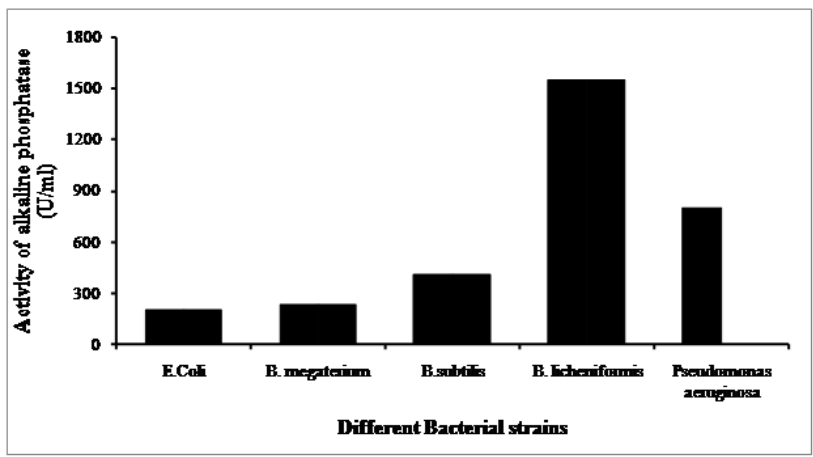

Fig. 4. Screening of bacterial strains on the basis of their ability to produce alkaline phoshatase.

zone of phosphate solubilization in compare to other strains. This visual analysis method has been considered as general reliable method for morphological characterization of phosphatesolubilizing-microbes $(3,7,8,24-26)$. Alkaline phosphatase activity was estimated for all the bacterial strains and maximum activity was found as $1550 \mathrm{U} \mathrm{ml}^{-1}$ for $B$. licheniformis MTCC 2312 as shown in Fig. 4. B. licheniformis MTCC 2312 was selected as potent bacterial strain for purification of alkaline phosphatase. Alkaline phosphatase was purified by fractional precipitation with $30-80 \%$ ammonium sulfate and DEAE column with purification fold 3.52 fold and $1.614 \%$ of recovery (Table 1). 
The specific activity for this enzyme was obtained as $95.89 \mathrm{U} \mathrm{mg}^{-1}$ of protein which showed high purity of this enzyme. The purified fraction of DEAE-sepharose column showed a molecular weight of $60 \mathrm{kD}$ after SDS-PAGE electrophoresis (Fig. 5). The low molecular weight of this enzyme is comparable with most alkaline phosphatases isolated from other bacterial strains like Bacillus, Pseudomonas (22, 27-31) which is lower than mammalian alkaline phosphatases (120-200 KD).

Table 1. Purification scheme of $B$. licheniformis MTCC1483 alkaline phosphatases by DEAE column chromatography.

\begin{tabular}{ccccc}
\hline $\begin{array}{c}\text { Purification } \\
\text { steps }\end{array}$ & $\begin{array}{c}\text { Total } \\
\text { Activity } \\
\text { (Unit) }\end{array}$ & $\begin{array}{c}\text { Total } \\
\text { protein } \\
\text { (mg) }\end{array}$ & $\begin{array}{l}\text { Specific } \\
\text { Activity } \\
\left(\mathrm{U} \mathrm{mg}^{-1}\right)\end{array}$ & $\begin{array}{c}\text { Purification } \\
\text { fold }\end{array}$ \\
\hline Crude Extract & 33803 & 402.56 & 83.97 & 1 \\
\hline $\begin{array}{c}\left(\mathrm{NH}_{4}\right)_{2} \mathrm{SO}_{4} \\
\text { precipitation }\end{array}$ & 28250 & 218.00 & 129.59 & 1.54 \\
\hline $\begin{array}{c}\text { DEAE- } \\
\text { Sepharose }\end{array}$ & 15650 & 52.89 & 295.89 & 3.52 \\
\hline
\end{tabular}

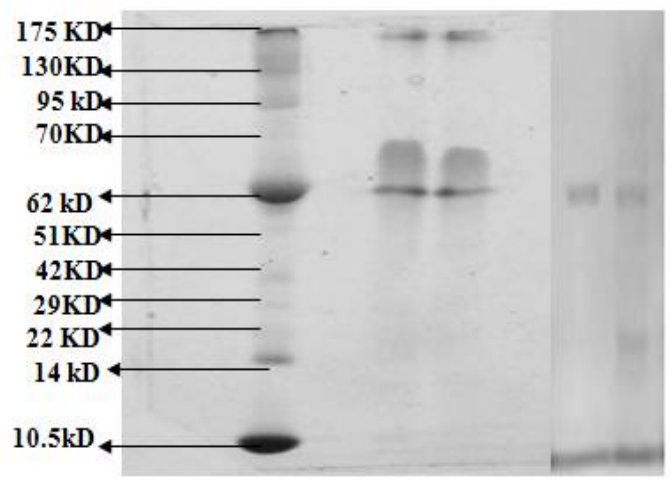

Fig. 5. Purified band for alkaline phosphatase for ladder (lane1), crude extract (Lane2), ammonium sulphate precipitation (lane3), fraction 1 of DEAE-Sepharose (Lane 4), fraction2 (lane 5).

The activity of alkaline phosphatase increased with increase of $\mathrm{pH}$ value from 6 and optimum activity was estimated at $\mathrm{pH} 8.5$ as shown in Fig. 6. The activity of this enzyme was found to be increased with increase of temperature and maximum activity was estimated at $50{ }^{\circ} \mathrm{C}$ (Fig. 7).

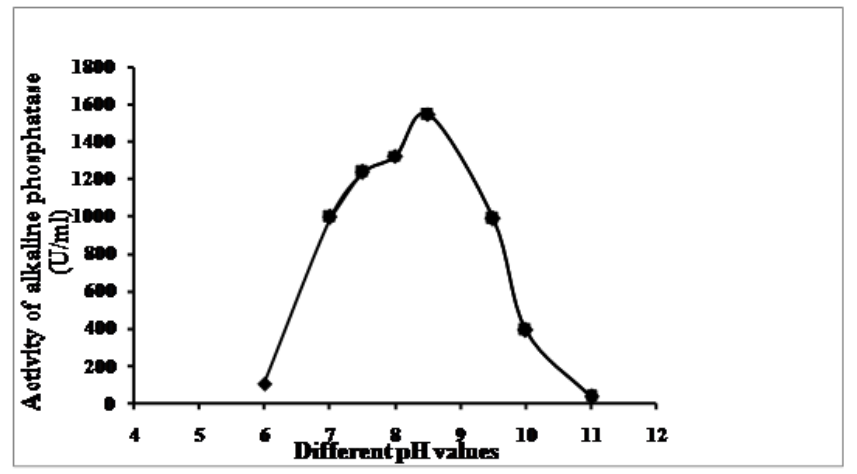

Fig. 6. Effect of $\mathrm{pH}$ on activity of alkaline phosphatase from $B$. licheniformis.

Alkaline phosphatases are non-specific to hydrolyse many phosphorylated substrates like phosphomonoesters, diesters and triesters (27-29, 32). In this study, purified alkaline phosphatase showed substrate specificity for a wide variety of phosphorylated compounds like para nitro-phenyl

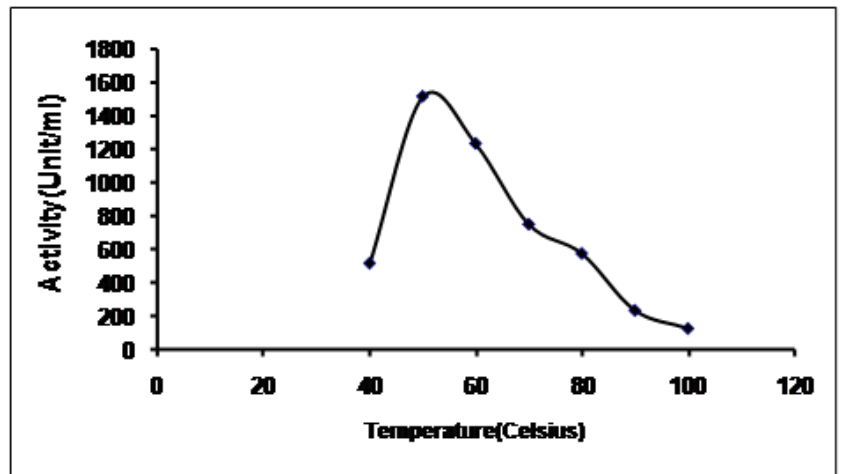

Fig. 7. Effect of temperature on activity of alkaline phosphatase from $B$. licheniformis.

phosphate, Guanosine mono-phosphate (GMP), Adenosine monophosphate (AMP), Adenosine DiPhosphate (ADP), Adenosine Tri-phosphate (ATP), Glucose-6-Phosphate and phosphoenol pyruvate (PEP) as shown in Table 2. Here monoesterphosphorous compounds like pNPP, GMP, AMP, PEP showed more specificity than diester or trimester compounds suggesting its phosphomonoesterase nature. The kinetic constant values of $\mathrm{K}_{\mathrm{m}}$ and $\mathrm{V}_{\max }$ was obtained as $2.30 \mathrm{mM}$ and $2223 \mathrm{U} \mathrm{ml}^{-1}$ respectively for this enzyme with para nitrophenyl phosphate sustrate. It is evident from Table 3 that alkaline phosphatse retained its 50\% activity upto $8 \mathrm{~h}$ which can be reported as its half life time. Alkaline phosphatase was found to be thermostable up to $50 \mathrm{~h}$ at temperature $50{ }^{\circ} \mathrm{C}$. The stability of alkaline phosphatase produced from $B$. licheniformis MTCC 2312 at high pH and high temperature is comparable to stability of alkaline phosphatase secreted from thermophilic bacteria (33-35).

Table 2. Effect of different substrate on hydrolysis of extracellular alkaline phosphatase from $B$. licheniformis.

\begin{tabular}{lc}
$\begin{array}{l}\text { Different types of phosphorylated } \\
\text { Substrates }\end{array}$ & Relative activity (\%) \\
\hline p-Nitrophenyl phosphate & 100 \\
\hline Glucose-6- Phosphate & 18.12 \\
\hline Adenosine monophosphate & 47.23 \\
\hline Adenosine diphosphate & 13.23 \\
\hline Adenosine triphosphate & 23.24 \\
\hline Guanosine monophosphate & 63.48 \\
\hline Phosphoenol Pyruvic acid & 12.41 \\
\hline
\end{tabular}

Table 3. Thermostability of alkaline phosphatase for different time interval at temperature $50{ }^{\circ} \mathrm{C}$

\begin{tabular}{ccc}
\hline Time (h) & $\begin{array}{c}\text { Alkaline Phosphatase } \\
\text { Activity (Unit } \mathbf{~ m}^{-\mathbf{1}} \text { ) }\end{array}$ & \% Thermostability \\
\hline 0 & 1550.00 & 100 \\
\hline 2 & 1304.24 & 86.95 \\
\hline 4 & 1173.71 & 78.25 \\
\hline 6 & 1063.18 & 70.88 \\
\hline 8 & 752.65 & 50.18 \\
\hline 10 & 531.59 & 35.44 \\
\hline 20 & 421.06 & 28.07 \\
\hline 40 & 378.95 & 25.26 \\
\hline 50 & 210.53 & 14.03 \\
\hline 100 & 0 & 0 \\
\hline
\end{tabular}


Some Bacillus spp. have phosphate solubilizing property and used as biofertilzer for improving crop productivity in alkaline soil due to having unique characteristic of producing stress resistant spores against high $\mathrm{pH}$ and high temperature range $(3,7,10)$. The solubilization of insoluble complex of phosphate into free inorganic phosphate has been reported in phosphate solubilizing microbes by secretion of various types of organic acids like malonic, gluconic, oxalic, glycolic, and succinic acid $(8,9,16,36,37)$. The hydrolysis of organic phosphorous compounds by these microbes has been reported due to secretion of phosphohydrolase enzymes. These dephosphorylation reactions are mainly caused by the hydrolysis of phosphoester or phosphoanhydride bonds in the presence of phosphohydrolases $(8,9,38-40)$.

The purified extract of alkaline phosphatase was lyophollized and its powder was supplemented with sterilized soil with calcium phosphate to observe its effect on growth and yield of Zea mays crop. The height of plant and total dry weight of $Z$. mays per pot was found to be increased by 3.07 and 3.15 fold in experimental sets compared to control (Table 4). The percentage of phosphate content in stem and root of $Z$. mays was also found to be increased by 2.35 and 1.76 fold respectively (Table 4). Phosphohydrolase enzymes secreted from some phosphate

Table 4. Estimation of plant growth, phosphatase activity and $\%$ phosphate content.

\begin{tabular}{ccccc}
\hline Treatments & $\begin{array}{c}\text { Height } \\
\text { plant } \\
\text { (cm) }\end{array}$ & $\begin{array}{c}\text { Total Dry } \\
\text { Weight (g) }\end{array}$ & \multicolumn{2}{c}{ \% phosphate } \\
\hline & & & Stem & Root \\
\hline${\text { Control } C_{1}}^{2}$ & 29.7 & 5.1 & 0.015 & 0.019 \\
\hline $\mathrm{C}_{2}$ & 33.9 & 4.9 & 0.026 & 0.023 \\
\hline $\mathrm{C}_{3}$ & 21.1 & 6.1 & 0.023 & 0.016 \\
\hline $\begin{array}{c}\text { Experimental } \\
\text { E1 }\end{array}$ & 78.4 & 15.5 & 0.058 & 0.035 \\
\hline E2 & 94.7 & 20.3 & 0.043 & 0.039 \\
\hline E3 & 87.2 & 14.9 & 0.049 & 0.028 \\
\hline
\end{tabular}

solubilizing microbes has the capability of hydrolysis of inorganic or organic phosphate to improve plant growth performance $(8,41)$. Many plants like potato, rice, sugar beet, tomato, lettuce, wheat, maize, sorghum, etc showed improved growth after supplementation of immobilized beads of phosphate solubilizing bacteria as biofertilizer $(8,9,42-47)$. There are no scientific reports available for use of the lyophilized powder of alkaline phopshatase to improve crop productivity in alkaline soil of arid region till date.

\section{Conclusion}

Alkaline phopshatase from $B$. licheniformis could be used as effective biofertilizer for agricultural industry to improve crop productivity. This microbial product has high range of $\mathrm{pH}$ stability along with thermostability and therefore could be used as biofertilizer to improve the crop productivity in arid region under severe climate condition.

\section{Conflict of interest}

The authors declare that they have no conflict of interest. This research article does not contain any studies with human participants or animals performed by any of the authors. This research work has not been funded by any funding agency.

\section{Acknowledgements}

The authors are grateful to Prof. Aditya Shastri, Vice Chancellor, Banasthali Vidyapith for providing all necessary support. We acknowledge the Bioinformatics Center, Banasthali Vidyapith supported by DBT for providing computation support, and DST for providing networking and equipment support through the FIST and CURIE programs at the Department of Bioscience and Biotechnology. CESME, Banasthali Vidyapith, supported by MHRD, Government of India under the PMMMNMTT is acknowledged for organizing the symposium.

\section{References}

1. Zhu HJ, Sun LF, Zhang YF, Zhang XL, Qiao JJ. Conversion of spent mushroom substrate to biofertilizer using a stresstolerant, phosphate-solubilizing Pichia farinos FL7. Bioresource Technology. 2012;11:410-16.

2. Sharma SB, Sayyed RZ, Trivedi MH, Gobi TA. Phosphate solubilizing microbes: sustainable approach for managing phosphorus deficiency in agricultural soils. Springer plus. 2013;2:587-600. https://doi.org/10.1186/2193-1801-2-587

3. Kalayu G. Phosphate solubilizing microorganisms: promising approach as biofertilizers. International Journal of Agronomy. 2019;1-7.

4. Halvorson HO, Keynan A, Kornberg HL. Utilisation of calcium phosphates for microbial growth at alkaline $\mathrm{pH}$. Soil Biological Biochemistry. 1990;22:887-90.

5. Azziz G, Bajsa N, Haghjou T, Taule C, Valverde A, Igual JM, Arias A. Abundance, diversity and prospecting of culturable phosphate solubilizing bacteria on soils under crop-pasture rotations in a no-tillage regime in Uruguay. Applied Soil Ecology. 2012;61:320-26. https://doi.org/10.1016/j.apsoil.2011.10.004

6. Tak HI, Ahmad F, Babalola OO, Inam A. Growth, photosynthesis and yield of chickpea as influenced by urban wastewater and different levels of phosphorus. International Journal of Plant Research. 2012;2:6-13. https://doi.org/10.5923/j.plant.20120202.02

7. Babalola OO, Glick BR. The use of microbial inoculants in African agriculture: current practice and future prospects. Journal of Food, Agriculture, and Environment. 2012b; $540-49$.

8. Kumar S, Bauddh K, Barman SC, Singh, RP. Amendments of microbial bio fertilizers and organic substances reduces requirement of urea and DAP with enhanced nutrient availability and productivity of wheat (Triticum aestivum L.). Ecological Engineering Journal. 2014;71:432-37. https://doi.org/10.1016/j.ecoleng.2014.07.007 
9. Jahan M, Mahallati MN, Amiri MB, Ehyayi HR. Radiation absorption and use efficiency of sesame as affected by biofertilizers inoculation, in a low input cropping system. Industrial Crops and products. 2013;43:606-11. https://doi.org/10.1016/j.indcrop.2012.08.012

10. David P, Raj RS, Linda R, Rhema SB. Molecular characterization of phosphate solubilizing bacteria (PSB) and plant growth promoting rhizobacteria (PGPR) from pristine soils. International Journal of Innovative Science Engineering and Technology. 2014;1:317-24.

11. Mamta RP, Pathania V, Gulati A, Singh B, Bhanwra RK, Tewari R. Stimulatory effect of phosphate-solubilizing bacteria on plant growth, stevioside and rebaudioside-A contents of Stevia rebaudiana Bertoni. Applied Soil Ecology. https://doi.org/10.1016/j.apsoil.2010.08.008

2010;46:222-29.

12. Zhao K, Penttinen P, Zhang X, Ao X, Liu M, Yu X, Chen Q Maize rhizosphere in Sichuan, China, hosts plant growth promoting Burkholderia cepacia with phosphate solubilizing and antifungal abilities. Microbiological Research. https://doi.org/10.1016/j.micres.2013.07.003

13. Istina IN, Widiastuti $\mathrm{H}$, Joy $\mathrm{B}$, Antralina M. Phosphate solubilizing microbe from Saprists peat soil and their potency to enhance oil palm growth and P uptake. Procidia Food Science. https://doi.org/10.1016/j.profoo.2015.01.047

2015;3:426-35

14. Chakraborty U, Chakraborty BN, Basnet M, Chakraborty, AP. Evaluation of Ochrobactrum anthropi TRS-2 and its talc based formulation for enhancement of growth of tea plants and management of brown root rot disease. Journal of Applied Microbiology. 2009;107:625-34. https://doi.org/10.1111/j.1365-2672.2009.04242.x

15. Fernandez Bidondo L, Silvani V, Colombo R, Pergola M, Bompadre J, Godeas A. Pre-symbiotic and symbiotic interactions between Glomus intraradices and two Paenibacillus species isolated from AM propagules. In vitro and in vivo assays with soybean (AG043RG) as plant host. Soil Biology and Biochemistry. 2011;43:1866-72. https://doi.org/10.1016/j.soilbio.2011.05.004

16. Halder AK, Mishra AK, Bhattacharya P, Chakrabarty PK. Solubilization of rock phosphate by Rhizobium and Bradyrhizobium. Journal of General Applied Microbiology. 1990;36:81-92.

17. Alori ET, Glick BR, Babalola OO. Microbial phosphorus solubilization and its potential for use in sustainable agriculture. Frontiers in Microbiology. 2017;8:971. https://doi.org/10.3389/fmicb.2017.00971

18. Surange S, Wollum II AG, Kumar N, Nautiyal CS. Characterization of Rhizobium from root nodules of leguminous trees growing in alkaline soils. Canadian Journal of Microbiology. 1997;43:891-94. https://doi.org/10.1139/m97-130

19. Gaind S, Gaur AC. Thermotolerant phosphate solubilizing microorganisms and their interaction with mung bean Plant Soil 1991;133:141-49. https://doi.org/10.1007/BF00011908

20. Liu M, Liu X, Cheng BS, Ma XL, Lyu XT, Zhao XF, et al. Selection and evaluation of phosphate-solubilizing bacteria from grapevine rhizospheres for use as biofertilizers. Spanish Journal of Agricultural Research. 2016;14:4 https://doi.org/10.5424/sjar/2016144-9714

21. El-Sersy NA, Ebrahim HAH, Abou-Elela GM. Response surface methodology as a tool for optimizing the production of antimicrobial agents from Bacillus licheniformis SN2. Current Research in Bacteriology. 2010;3(1):1-14. https://doi.org/10.3923/crb.2010.1.14

22. Garen A, Levinthal C. A fine-structure genetic and chemical study of the enzyme alkaline phosphatase of $E$. coli. 1 - Purification and characterization of alkaline phosphatase. Biochimica et Biophysica Acta. 1960;38:470 83. https://doi.org/10.1016/0006-3002(60)91282-8

23. Lowry $\mathrm{OH}$, Lopez JA. The determination of inorganic phosphate in the presence of labile phosphate esters. Journal of Biological Chemistry. 1946;162:421-28.

24. Darmwall NS, Singh RB, Rai R. Isolation of phosphate solubilizers from different sources. Current Science. 1989;58:570-71.

25. Bardiya MC, Gaur AC. Isolation and screening of microorganisms dissolving low grade rock phosphate. Folia Microbiology. 1974;19:386-89. https://doi.org/10.1007/ BF02872824

26. Katznelson $\mathrm{H}$, Peterson EA, Rovatt JW. Phosphate dissolving microoganisms on seed and in the root zone of plants. Canadian Journal of Botany. 1962;40:1181-86 https://doi.org/10.1139/b62-108

27. Kostadinova S, Marhova M. Purification and Properties of Alkaline Phosphatase from Bacillus cereus. Biotechnology \& Biotechnological Equipment. 2010;24:602-06. https://doi.org/10.1139/b62-108

28. Dhaked RK, Alam SI, Dixit A, Singh L. Purification and characterization of thermolabile alkaline phosphatase from an Antarctic psychrotolerant Bacillus sp. P9. Enzyme Microbial Technology. 2005;36:855-61. https://doi.org/10.1016/j.enzmictec.2004.11.017

29. Goldman S, Hecht K, Eisenberg H, Mevarech $M$ Extracellular $\mathrm{Ca}^{2+}$-dependent inducible alkaline phosphatase from the extremely halophilic archeabacterium Haloarcula marismortui. Journal of Bacteriology. 1990; 172:7065-70 https://doi.org/10.1128/JB.172.12.7065-7070.1990

30. Fitt PS, Peterkin PI. Isolation and properties if a small manganese-ion- stimulated bacterial alkaline phosphatase. Biochemical Journal. https://doi.org/10.1042/bj1570161

1976;157:161-67.

31. Posen S. Alkaline phosphatase. Annals of Internal Medicine. 1967;67:183-203. https://doi.org/10.7326/00034819-67-1-183

32. Morales AC, Nozawa SR, Thedei G, Maccheroni W, Rossi A. Properties of a constitutive alkaline phosphatase from strain $74 \mathrm{~A}$ of the mold Neurospora crassa. Brazilian Journal of Medical and Biological Research. 2000;33:90512. https://doi.org/10.1590/S0100-879X2000000800006

33. Yeh MF, Trela JM. Purification and characterization of a repressible alkaline phosphatase from Thermus aquaticus. Journal of Biological Chemistry. 1976;251:3134-39.

34. Dong GQ, Zeikus JG. Purification and characterization of alkaline phosphatase from Thermotoga neapolitana. Enzyme Microbial Technology. 1997;21:335-40. https://doi.org/10.1016/S0141-0229(97)00002-1

35. Wojciechowski CL, Cardia JP, Kantrowitz ER. Alkaline phosphatase from the hyperthermophilic bacterium $T$. maritima requires cobalt for activity. Protein Science. 2002;11:903-11. https://doi.org/10.1110/ps.4260102

36. Duff RB, Webley DM. 2-Ketogluconic acid as a natural chelator produced by soil bacteria. Chemistry and Industry (London). 1959;1376-77.

37. Banik S, Dey BK. Available phosphate content of an alluvial soil is influenced by inoculation of some isolated phosphate-solubilizing microorganisms. Plant Soil. 1982;69:353-64. https://doi.org/10.1007/BF02372456

38. Ohtake $\mathrm{H}, \mathrm{Wu} \mathrm{H}$, Imazu K, Ambe Y, Kato J, Kuroda A. Bacterial phosphonate degradation, phosphite oxidation and polyphosphate accumulation. Resource Conservation and Recycling. 1996;18:125-34. https://doi.org/10.1016/S0921-3449(96)01173-1 
39. McGrath JW, Wisdom GB, McMullan G, Lrakin MJ, Quinn, JP. The purification and properties of phosphonoacetate hydrolase, a novel carbon-phosphorus bond-cleaving enzyme from Pseudomonas fluorescens 23F. European Journal of Biochemistry. 1995;234:225-30. https://doi.org/10.1111/j.1432-1033.1995.225 c.x

40. Bujacz B, Wieczorek P, Krzysko-Lupcka T, Golab Z, Lejczak B, Kavfarski P. Organophosphonate utilization by the wildtype strain of Penicillium notatum. Applied Environmental Microbiology. https://doi.org/10.1128/AEM.61.8.2905-2910.1995

41. Krasilnikov M. On the role of soil bacteria in plant nutrition. Journal of General and Applied Microbiology. 1961;7:128-44. https://doi.org/10.2323/jgam.7.128

42. Hall JA, Pierson D, Ghosh S, Glick BR. Root elongation in various agronomic crops by the plant growth promoting rhizobacterium Pseudomonas putida GR12-2. Israel Journal of Plant $\quad$ Sciences. 1996;44:37-42. https://doi.org/10.1080/07929978.1996.10676631

43. Glick BR, Changping L, Sibdas G, Dumbroff EB. Early development of canola seedlings in the presence of the plant growth-promoting rhizobacterium Pseudomonas putida GR12-2. Soil Biological Biochemistry. 1997;29:123339. https://doi.org/10.1016/S0038-0717(97)00026-6

44. Kloepper JW, Lifshitz K, Schroth MN. Pseudomonas inoculants to benefit plant production. ISI Atlas of Science: Animal and Plant Sciences. 1988;60-64.

45. Kapulnik J, Gafny R, Okon Y. Effect of Azopirillum spp. inoculation on root development and NO-3 uptake in wheat (Titicum aestivum cv. Miriam) in hydroponic systems. Canadian Journal of Botany. 1985;63:627-31. https://doi.org/10.1139/b85-078

46. Broadbent P, Baker KF, Franks N, Holland J. Effect of Bacillus spp. on increased growth of seedlings in steamed and in nontreated soil. Phytopathology. 1977;67:1027-34. https://doi.org/10.1094/Phyto-67-1027

47. Burr TJ, Schroth MN, Suslow T. Increased potato yields by treatment of seedpieces with specific strains of Pseudomonas fluorescens and Pseudomonas putida. Phytopathology. https://doi.org/10.1094/Phyto-68-1377
1978;68:1377-83. 